\title{
Mapping Indigenous Nutrient Status of Post-Eruption Soil to Support the Fertilization of Rice (Oryza sativa) in the Southern Area of Merapi Mountain, Indonesia
}

\author{
Eko Amiadji JULIANTO' ${ }^{*}, 2$, Suntoro SUNTORO3, Widyatmani Sih DEWI3, Partoyo PARTOYO² \\ *Corresponding author \\ ${ }^{1}$ Sebelas Maret University of Surakarta, Graduate School, Doctoral Program of Agricultural Science, Surakarta, INDONESIA \\ 2 Universitas Pembangunan Nasional Veteran Yogyakarta, Faculty of Agriculture, Department of Soil Science, Yogyakarta, \\ INDONESIA \\ ${ }_{3}$ Sebelas Maret University of Surakarta, Faculty of Agriculture, Department of Soil Science, Surakarta, INDONESIA \\ E-mail: ekoamiadji@yahoo.com, suntoro_uns@yahoo.co.id,wsdewi2ooo@gmail.com,partoyo@upnyk.ac.id
}

DOI: 10.24193/JSSP.2019.1.03

https://doi.org/10.24193/JSSP.2019.1.03

K e y w o r d s: $P_{2} \mathrm{O}_{5}, \mathrm{~K}_{2} \mathrm{O}$, base saturation, kriging method, fertilization, map of recommendations, soil, Indonesia

\begin{abstract}
A B S T RA C T
This study aims to discuss a technique of digital soil mapping to recommend fertilization options based on the major indigenous soil nutrients. The southern slope of Merapi Mountain in Yogyakarta, Indonesia, was selected to conduct the research. Thirty-seven areas included in five sub-districts were chosen as soil sampling locations based on a stratified purposive sampling technique. The boundary of each area on the map was delineated using the kriging method. The collected soil samples were analyzed for indigenous content of available phosphorus, total potassium, and soil base saturation. The soil data were used as a basis for creating maps of available phosphorus content, total potassium content, and soil base saturation. The criteria for evaluating the level of soil nutrient content and for proposing fertilizer recommendation were developed according to criteria acknowledged by the Indonesian Soil Research Centre [ID: Pusat Penelitian Tanah (PPT)]. Results showed that the base saturation of the soil in the study area was dominantly classified as medium (41-60\%) and high (6o-80\%). Phosphorus $\left(\mathrm{P}_{2} \mathrm{O}_{5}\right)$ was found very highly available $(>60 \mathrm{mg} / 100 \mathrm{~g}$ of soil) and total potassium was dominantly very low ( $<10 \mathrm{mg} / 100 \mathrm{~g}$ of soil) and low (10-20 mg/100g of soil). Based on this results, fertilizer need for rice cultivation in the study area is recommended to follow recommendations revealed in map 2 of potassium chloride (KCl), which for the low potassium level area is of $50 \mathrm{~kg} / \mathrm{ha}$ of $\mathrm{KCl}+$ harvested rice straw, whereas for the medium potassium level area is of o kg/ha of $\mathrm{KCl}+$ harvested rice straw. In conclusion, the fertilization of irrigated rice plant should not be done uniformly.
\end{abstract}

\section{INTRODUCTION}

The Global Positioning System (GPS) has very wide adaptability in agriculture studies namely in the preparation of thematic maps such as land use, land cover, soil fertility maps, etc. The determination of the status of soil available nutrients in an area by using GPS helps formulate site-specific nutrient management and understand the status of soil fertility spatially and temporally (Rao and Srivastava, 2000; Vadivelu, 2007). Geographical Information System (GIS) provides valuable support to handle big data, which are generated through conventional and spatial format. GPS and GIS-based soil fertility maps were elaborated for different areas of other states (Sharma et al., 2008; Muralidharudu et al., 2011; Nahak et al, 2016). In relation to the logistics of fertilizers, a map of the soil nutrient status in a region should be available. The map 
of nutrient status is extremely helpful in predicting the proper amount of fertilizer needed in a region. In the research area, a map of nutrient status is required especially for phosphorus (P) and potassium (K) nutrients. Mapping the nutrient status is important to reveal specifically delineated areas and recommended dosages of fertilizers based on the homogeneity of the biophysical and socio-economic characteristics of farming activities (Dobermann et al., 2003a).

Further, Dobermann et al. (2003b) stated that the variability of soil fertility is very important to be considered as a basis for developing fertilizer recommendations. Specific Location Nutrient Management (SLNM) is one approach that can be implemented through an evaluation of the indigenous nutrient supply from the soil. This approach recommends that fertilization of irrigated paddy-fields should not be done uniformly. Recommendations on fertilization that ignore the variability of climate, soil conditions (physical, biological, and chemical properties) and plant management have a low degree of accuracy, thereby reducing efficiency in the use of input, limiting productivity and benefits of farming operations (Haefele et al., 2000).

The soil fertility level was evaluated from the composite soil samples collected from the field. Soil samples were then analyzed to determine their nutrient status. Locations of soil samples were determined by using GPS so that they could be plotted on a basic map. This is similar to the research conducted by Muralidharudu et al. (2011) in India. However, this method required a relatively high cost for soil sampling and soil fertility analysis for each new location. Producing a map of soil fertility can be used as a guiding tool for the implementation of fertilizer recommendations in any location. The digital soil mapping provided a technique for making a map of soil fertility quantitatively based on soil observation and any other supporting data.

This study aims to discuss a technique of digital soil mapping for the development of fertilizer recommendations based on data related to the major soil indigenous nutrients. This research wants to emphasize that information about the indigenous nutrient status of the soil (phosphorus and potassium) can be used to support soil fertilization recommendations. The output of this research consists of several maps of soil nutrient level and a map of fertilizer recommendation that can support fertilization of irrigated paddy-fields used for growing rice (Oryza sativa). The novelty of this research lies in the mixed use of spatial data showed by geographic maps and of attribute data of soil fertility. The steps followed to obtain the map include the following: mapping the demonstration plot; mapping the soil nutrient level; and mapping the fertilizer recommendations. Although these steps are time-consuming and complicated, the fertilizer recommendation maps will be applicable and will greatly assist farmers in making the decision for the proper dosage of fertilizer for irrigated rice-fields. This research is original and has never been previously done, especially by the combination of geographic map and soil fertility map of the southern slope of Merapi Mountain in Sleman Regency, Province of the Special Region of Yogyakarta, Indonesia.

\section{THEORY AND METHODOLOGY}

The research was conducted in the southern area of Merapi Mountain (sub-districts of Cangkringan, Pakem, Turi, Tempel, and Seyegan) in Sleman Regency, Province of the Special Region of Yogyakarta, Indonesia from April 2015 to April 2016. The observation was done by collecting soil samples from several locations (37 stations of irrigated paddy-field) determined by using stratified purposive sampling technique. Stratified purposive sampling is different from stratified random sampling in that sample sizes are likely to be too small for generalization. Patton (2001) described these as samples within samples and suggested that purposeful samples can be stratified or nested by selecting particular units or cases that vary according to a key dimension. In this study, the irrigated paddy-field is used as the main basis for the map of soil (unit and extent). Each point of observation was plotted on the fieldwork map and their geographical position (coordinate) were determined, then they were traced in the field and a soil sample was taken by using GPS navigation.

Soil samples were analyzed in the laboratory to determine their available phosphorus and potassium content and base saturation. These three parameters were required as criteria to propose fertilizer recommendations (Makarim et al., 2003). Phosphorus content was determined by the Olsen method. The soil was extracted using $\mathrm{NaHCO}_{3}$ 0.5M pH 8.5 solution and the phosphorus content was measured by spectrophotometer using wavelength $889 \mathrm{~nm}$ (ISRIC, 1993). Potassium content was determined by extracting soil sample with $1 \mathrm{M} \mathrm{NH} 4 \mathrm{OAc} \mathrm{pH} 7$ and measured for potassium content by flame-photometer. The soil extract was also measured for determining $\mathrm{Ca}, \mathrm{Mg}$, and $\mathrm{Na}$ content. Cation-exchange capacity (CEC, $\mathrm{cmol}(+) / \mathrm{kg}$ ) was measured by the distillation of the $\mathrm{NH} 4 \mathrm{OAc}$ soil extract using the $\mathrm{N}$-Kjeldahl method (Burt, 2004). Base saturation (\%) was calculated from the percentage of exchangeable cation $(\mathrm{Ca}, \mathrm{Mg}, \mathrm{K}, \mathrm{Na}$ ) compared to the soil CEC (Prasetyo et al., 2012).

The map of soil indigenous nutrient status was created based on data related to phosphorus content, potassium content, and base saturation of soil samples. The polygon boundary on the map was developed using the kriging method. Cressie (1990) stated that the kriging method is a method of interpolation for which 
the interpolated levels are modelled by a Gaussian process governed by prior co-variances, as opposed to piecewise-polynomial spline, chosen to optimize smoothness of the fitted level. Under suitable assumptions on the priors, kriging gives the best linear unbiased prediction of the intermediate level. In addition to researching the soil, the kriging-based approach is also used by some researchers to examine soil content. Küçüker et al. (2010) applied the krigingbased estimation of the change in soil carbon stock in the coastal Black Sea region, Turkey. Mushtaq et al. (2013) researched the ordinary kriging and indicator approach on the mapping of soil micronutrients in Kashmir agricultural landscape. Shukla et al. (2015) estimated the deficient micronutrients in the soil with kriging approach in Kashi Vidyapeeth block of Varanasi District of Uttar Pradesh, India.

Fertilizer recommendations were developed based on the map of soil nutrient status according to the criteria acknowledged by the Indonesian Soil Research Centre (Makarim et al., 2003). The fertilizer recommendation criteria have been proven to be adequate for irrigated rice-field and already widely implemented in Java Island, Indonesia.

\section{RESULTS AND DISCUSSION}

\subsection{The framework of digital soil mapping based on the major indigenous soil nutrient supply}

Digital Soil Mapping (DSM) can be defined as the creation and population of spatial soil information systems by the use of field and laboratory observational methods coupled with spatial and non-spatial soil inference systems (Lagacherie and McBratney, 2007; Lagacherie, 2008). Another term used for DSM is Predictive Soil Mapping (PSM). Scull et al. (2003) explained that PSM can be defined as the development of a numerical or statistical model of the relationship among environmental variables and soil properties, which is then applied to a geographic database to create a predictive map. Predictive Soil Mapping (PSM) is made possible by geo-computational technologies developed over the past few decades. In addition, Digital Soil Mapping (DSM) can also be referred to as Quantitative Soil Survey (QSS). McKenzie and Ryan (1999) stated that QSS as conventional survey methods are efficient for medium to low-intensity surveys because they use relationships between soil properties and more readily observable environmental features as a basis for mapping. However, the implicit predictive models are qualitative, complex and rarely communicated in a clear manner. The possibility of developing an explicit analogue of conventional survey practice suited to medium to low-intensity surveys is considered. A key feature is the use of quantitative environmental variables from digital terrain analysis and airborne gamma radiometric remote-sensing to predict the spatial distribution of soil properties (McKenzie and Ryan, 1999). DSM can be applied using two major stages in digital soil mapping based on the data regarding the major indigenous soil nutrients, i.e. (i) supply of a data set of the major indigenous soil nutrients; (ii) digital soil mapping of the status of the major indigenous soil nutrients (Bui, 2007). The conceptual framework, which also serves as a frame of reference applied in this research, is presented in Figure 1. The first stage is the supply of the data set of the soil fertility factor, consisting of various co-variants, which represent one or several factors, namely $\mathrm{P}_{2} \mathrm{O}_{5}, \mathrm{~K}_{2} \mathrm{O}$, and base saturation. The second stage includes the following actions: mapping the distribution of irrigated rice-field, digital soil mapping of the status of the major indigenous nutrient content of the soil, mapping the $\mathrm{P}_{2} \mathrm{O}_{5}, \mathrm{~K}_{2} \mathrm{O}$ and base saturation status of soil, as well as the elaboration of a map with recommendations on $\mathrm{KCl}$ and Super Phosphate-36 fertilizer (SP-36) for the southern area of Merapi Mountain in Sleman Regency, Province of the Special Region of Yogyakarta, Indonesia. Farmers in Indonesia usually use $\mathrm{KCl}$ fertilizer to compensate for the deficit in $\mathrm{K}_{2} \mathrm{O}$ in the soil and SP-36 fertilizer to adjust the quantity of $\mathrm{P}_{2} \mathrm{O}_{5}$ in the soil. SP-36 is a phosphate fertilizer with a content of $36 \%$ phosphate.

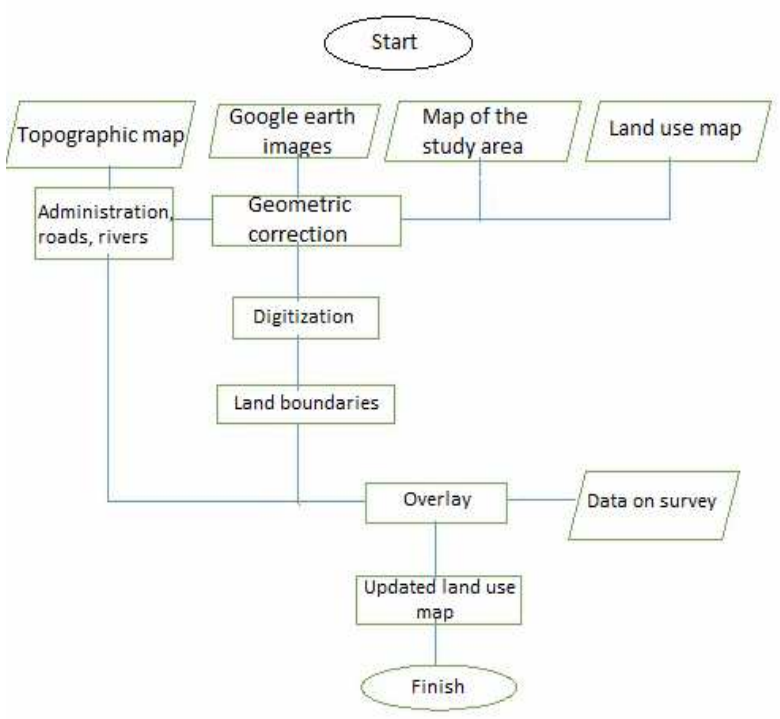

Fig. 1. Flow chart of the elaboration of the land use map.

The stages in the elaboration of land use map (distribution of irrigated rice field) are as follows:

1). Data collection in an analogue and digital form: Digital Topographic Map of Sleman Regency, issued by the Geospatial Information Agency; Google Earth Images of the Sleman Regency area, captured from Google Earth Inc.; Map of the Agricultural Area, issued by the Regional Development Agency of Sleman 
Regency; Land Use Map, issued by the Regional Development Agency of Sleman Regency; Field Survey, carried out in 2017.

2). Geometric correction of Google Earth Images, which is a process of positioning images in accordance with the coordinates on the actual map. GIS software was used to operate corrections.

3). Digitization of the boundaries of irrigated rice fields, dry fields, and non-agricultural land.

4). Validation of digitization results by integrating data of both the map of agricultural area and the land use map.

5). After digitization, we combined the data on the Digital Topographic Map with the data from the field survey.

6). Layout creation and a map of land use was obtained (map of the distribution of irrigated rice field).

\subsection{Digital soil mapping of the southern area of Merapi Mountain}

Digital soil mapping was preceded by taking the coordinates of each location in the experiment stations. The 37 experiment stations were scattered in five sub-districts, namely Cangkringan, Pakem, Turi, Tempel, and Seyegan. The observation of Soil Fertility Evaluation (SFE) was done by collecting soil samples. The geographical positions of each observation point were determined, and marked on the fieldwork map; then, they were traced in the field by GPS navigator and soil samples were collected. Soil samples were analyzed in the laboratory to determine $\mathrm{P}_{2} \mathrm{O}_{5}, \mathrm{~K}_{2} \mathrm{O}$ content and base saturation. The locations of soil sample collection are presented in Figure 2.

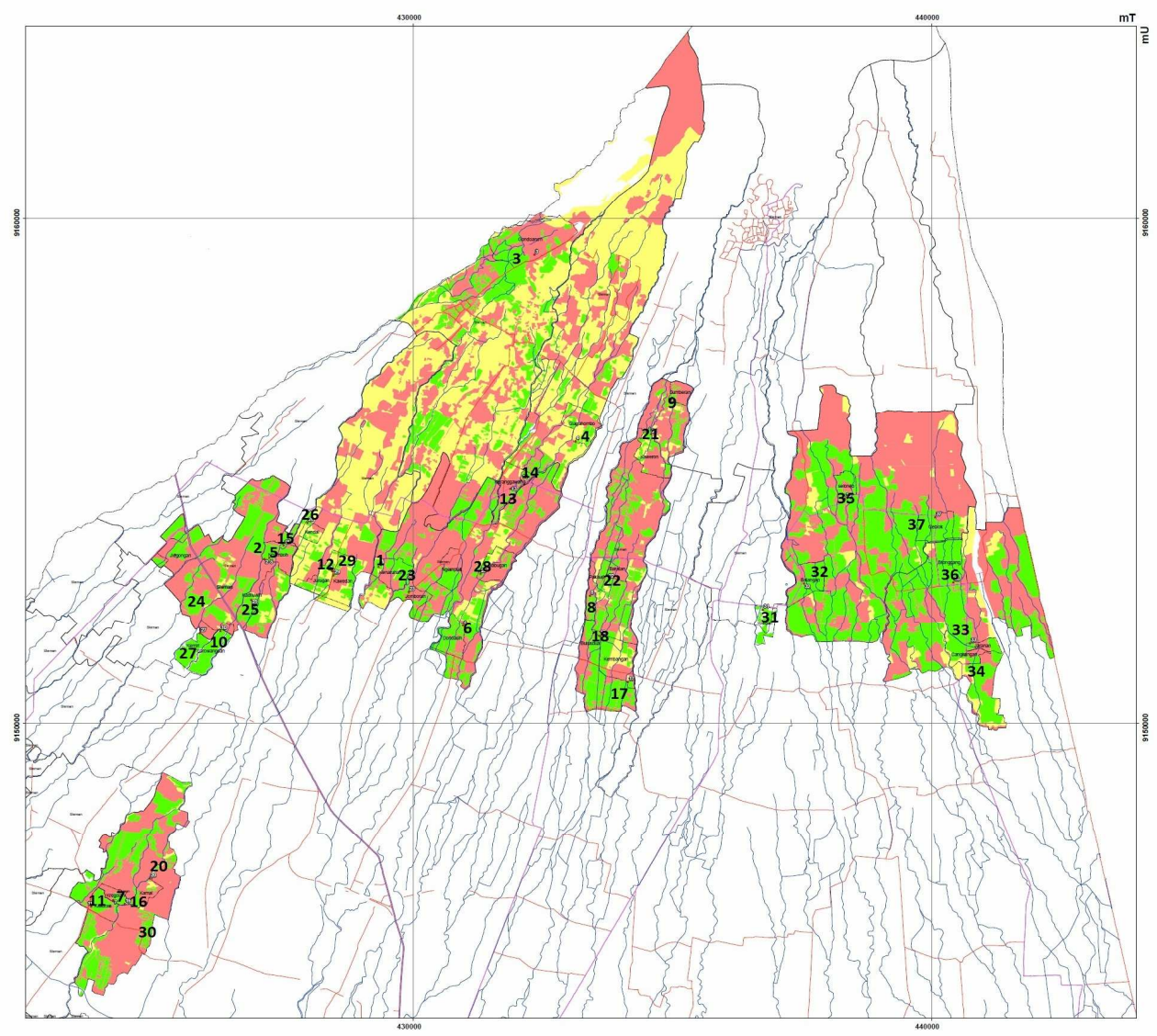
Sub-District Cangkringan, Pakem, Turi, Tempel, Seyegan
District Sleman Province Daerah Istimewa Yogjakarta Legend:

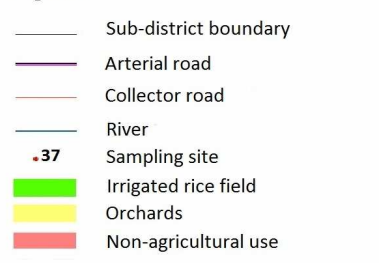

Fig. 2. The locations of soil sample collection (37 demonstration plots).

\subsection{Soil nutrient level map}

In soil fertility research, the study should develop of variety of models, so that the maps of soil fertility can be further selected for a better representation of the soil fertility distribution. In order to obtain the map of $\mathrm{P}_{2} \mathrm{O}_{5}, \mathrm{~K}_{2} \mathrm{O}$ and base saturation level we evaluated the nutrient level based on criteria acknowledged by the Food and Agriculture Organisation (FAO, 1977) and the Indonesian Soil Research Centre (Pusat Penelitian Tanah, 1983). By checking the location on the map of the nutrient level, users (farmers) could be informed about the nutrient status of their irrigated rice-fields.

Figure 3 shows that the $\mathrm{P}_{2} \mathrm{O}_{5}$ level along the southern area is very high ( $>60 \mathrm{mg} / 100 \mathrm{~g}$ of soil). This shows that, potentially, the soil contains very high $\mathrm{P}_{2} \mathrm{O}_{5}$. Adiningsih et al. (1989) stated that the use of phosphate in paddy-fields should be evaluated to sustain soil fertility in the long term. This is supported by several researchers in Indonesia, who stated that the $\mathrm{P}_{2} \mathrm{O}_{5}$ content in the soil in paddy-fields, which are intensively 
Mapping Indigenous Nutrient Status of Post-Eruption Soil to Support the Fertilization of Rice (Oryza sativa) in the Southern Area of Merapi Mountain, Indonesia

Journal Settlements and Spatial Planning, vol. 10, no. 1 (2019) 29-38

fertilized on Java island, tend to be high

Rochayati and Adiningsih, 2002).

(Abdulrachman et al., 2000; Harahap et al., 2002;

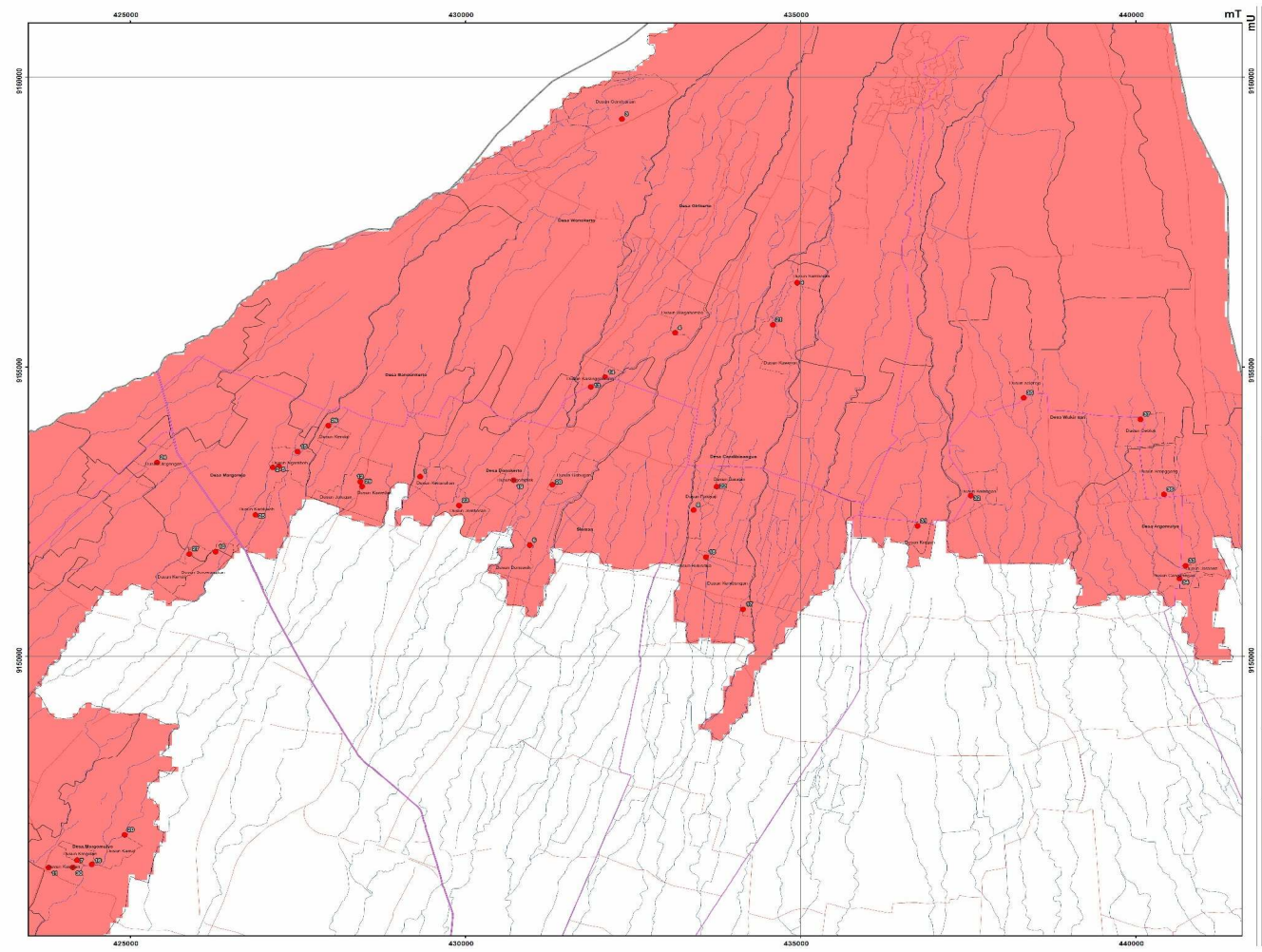

MAP OF P2O5 LEVEL OF SOIL

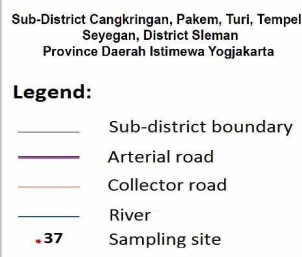

Level of P2O5 content

늘 $>60 \mathrm{mg} / 100 \mathrm{~g}$ of soil (Very high)

Fig. 3. Map of $\mathrm{P}_{2} \mathrm{O}_{5}$ level (mg/10og of soil) in the southern area of Merapi Mountain.

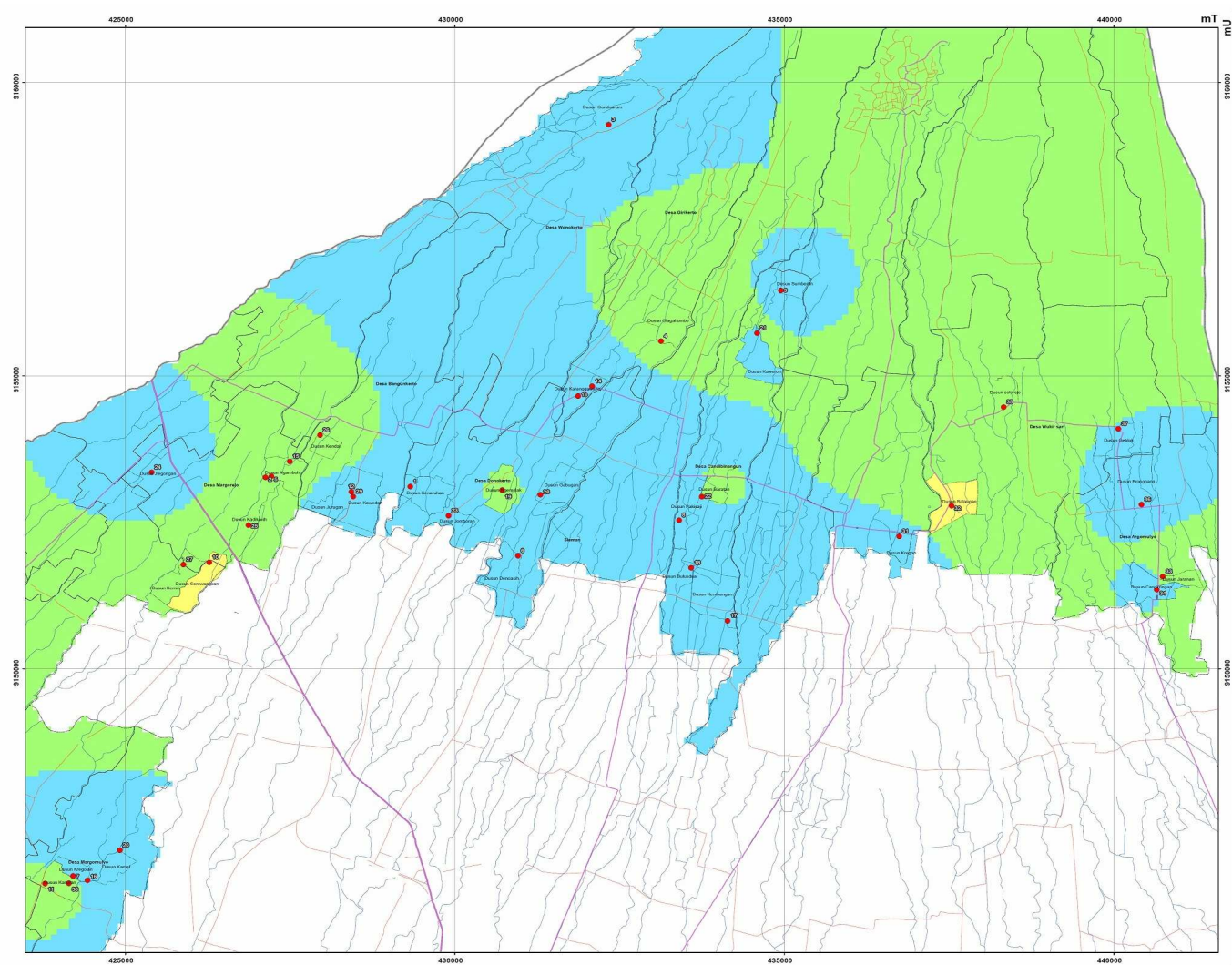

MAP OF POTASSIUM CONTENT Sub-District Cangkringan, Pakem, Turi, Tempel Seyegan, District Sleman
Province Daerah Istimewa Yogjakarta

Legend:

Sub-district boundary

Arterial road

Collector road

$\begin{array}{ll}.37 & \text { River } \\ & \text { Sampling site }\end{array}$

K2O content (mg/100g soil)

$<10 \quad$ (Low)

$10-20$ (Medium)

$21 \quad 40$ (High)

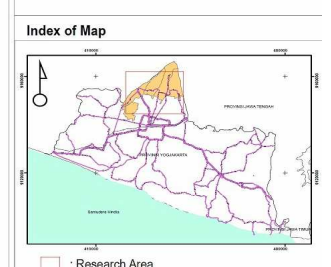

sente

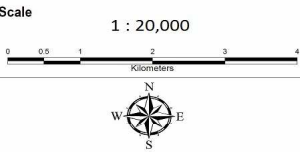

Projection
Grid System :Universal Transverse Mecator

:WGS 1984 Zona $49 \mathrm{~S}$

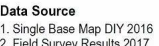

2. Field Survey Results 2017

Fig. 4. Map of $\mathrm{K}_{2} \mathrm{O}$ level (mg/10og of soil) in the southern area of Merapi Mountain.

The challenge in the future is how to convert the unavailable phosphorus into an available form
$\left(\mathrm{H}_{2} \mathrm{PO}_{4}^{-}, \mathrm{HPO}_{4}^{2}\right)$. Continuous fertilization with SP-36 has a negative impact on soil and it is not economically 
feasible. This is also confirmed by Mkhabela and Warman (2005) in their research in a Pugwash sandy loam soil in Nova Scotia and by Ming et al. (2011) in a paddy soil of subtropical China.

Figure 4 shows that the $\mathrm{K}_{2} \mathrm{O}$ level along the southern area is dominantly low ( $<10 \mathrm{mg} / 100 \mathrm{~g}$ of soil) and medium (10-20 mg/10og of soil). A number of spots on the south side record a high level (21-40 $\mathrm{mg} / 100 \mathrm{~g}$ of soil), on the east side a medium level, and on the west side, they have a low level. This is apparently caused by the fact that the east side is potentially supplied with potassium-rich material from the Merapi Mountain flowed along the Gendol river.
Figure 5 shows that the base saturation level along the southern area is dominantly medium (41$60 \%)$ and high (61-80\%). There is a spot in the southern part with a very high level of base saturation (>80\%). The base saturation level that tends to be high is apparently caused by the addition of new materials from the eruption of Merapi Mountain. The result of analysis shows that the base saturation of erupted Merapi Mountain mineral is $8.78 \%$, consisting of cations of calcium $7.44 \mathrm{cmol}(+) / \mathrm{kg}$, magnesium 0.96 $\mathrm{cmol}(+) / \mathrm{kg}$, potassium $0.17 \mathrm{cmol}(+) / \mathrm{kg}$ and sodium $0.21 \mathrm{cmol}(+) / \mathrm{kg}$.

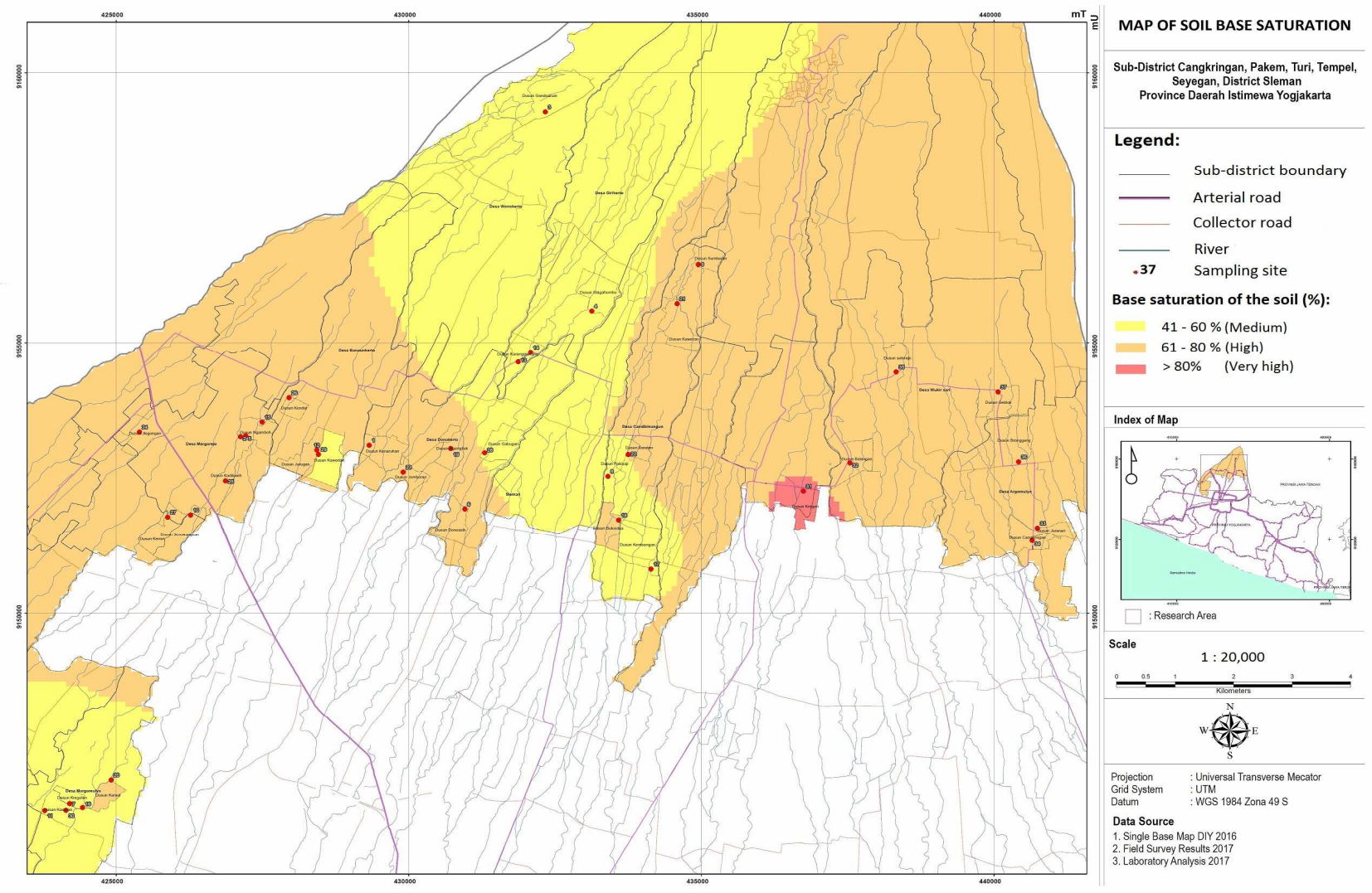

Fig. 5. Map of base saturation level (\%) in the southern area of Merapi Mountain.

\subsection{Map of fertilizer recommendations}

Fertilizer recommendations were proposed based on the map of $\mathrm{P}_{2} \mathrm{O}_{5}$ and $\mathrm{K}_{2} \mathrm{O}$ level. The recommended dosage of fertilizer proposed by this research is based on the criteria published by the Indonesian Rice Research Centre (Makarim et al., 2003). The recommendations were proposed by using the most popular fertilizer available in the research area, i.e. for potassium is potassium chloride $(\mathrm{KCl})$ and for phosphorus is SP-36. The recommendation for potassium is provided as a recommendation map of $\mathrm{KCl}$ alternative-1 (using only $\mathrm{KCl}$ fertilizer) and alternative2 (a combination of $\mathrm{KCl}$ fertilizer and rice straw) (Fig. 6), whereas for phosphorus is provided as recommendation map of SP-36 fertilizer.
For some areas, having abundant rice straw after rice harvesting, it is highly recommended to apply the $\mathrm{KCl}$ recommendation alternative 2 . It is very much beneficial to sequestrate carbon back into the soil, as well as to reduce the amount of $\mathrm{KCl}$ fertilizer required.

Figure 6 shows that the level of $\mathrm{K}_{2} \mathrm{O}$ along the southern slopes of Merapi Mountain is mainly low to medium. According to Makarim et al. (2003), the fertilizer dosage recommended for the low $\mathrm{K}_{2} \mathrm{O}$ level is $100 \mathrm{~kg} / \mathrm{ha}$ of $\mathrm{KCl}$, while for the medium $\mathrm{K}_{2} \mathrm{O}$ level is of $50 \mathrm{~kg} / \mathrm{ha}$ of $\mathrm{KCl}$. By using this $\mathrm{KCl}$ recommendation map, it will be easier for the farmers to decide the appropriate amount of fertilizer required for their specific location since the different soil nutrient levels are clearly delineated on the map. Users will just plot the location of the paddy-fields on the map and then 
Mapping Indigenous Nutrient Status of Post-Eruption Soil to Support the Fertilization of Rice (Oryza sativa) in the Southern Area of Merapi Mountain, Indonesia

Journal Settlements and Spatial Planning, vol. 10, no. 1 (2019) 29-38

check for the similar colour on the map legend to get the amount of fertilizer needed.

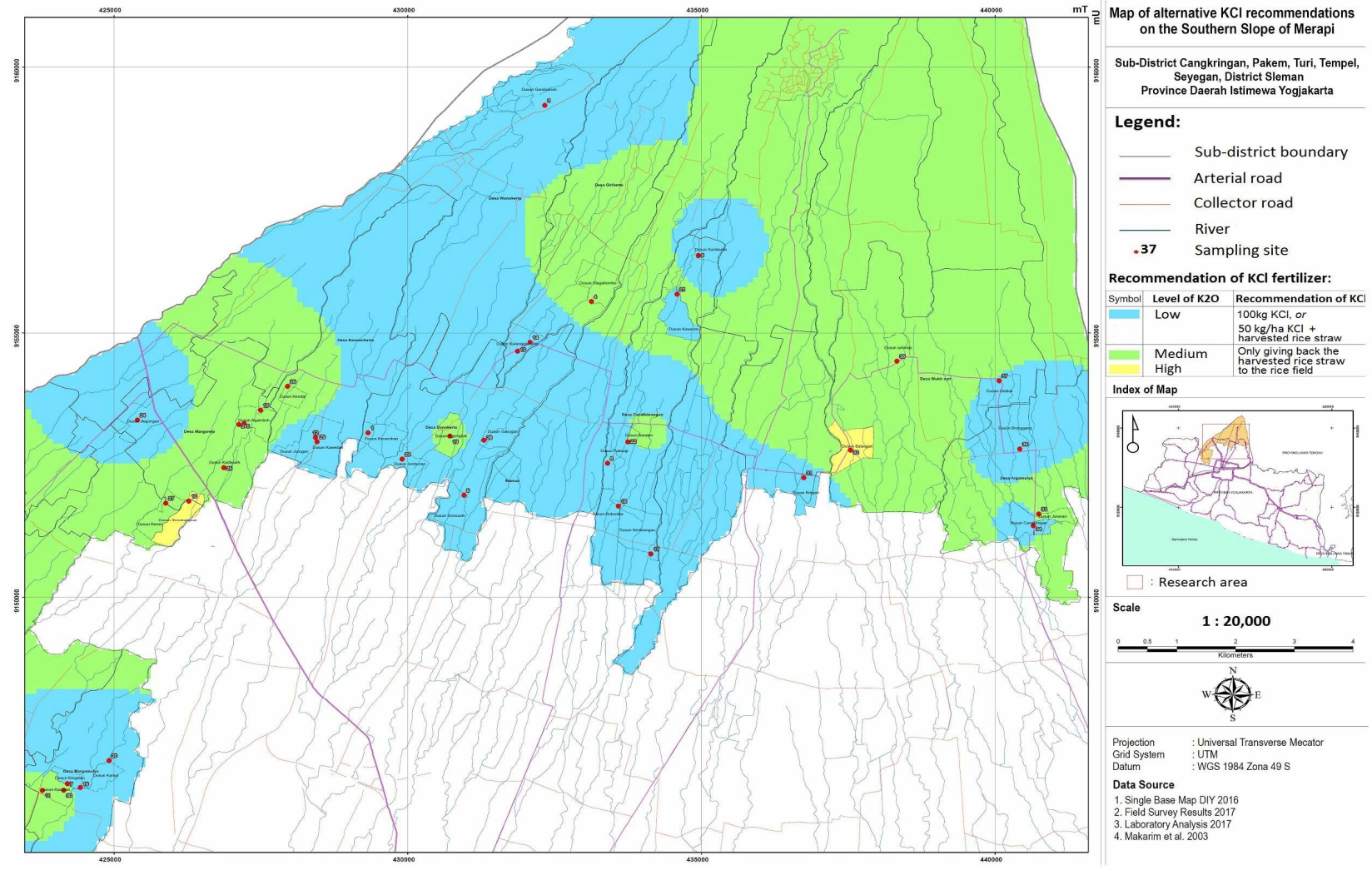

Fig. 6. Recommendation map of $\mathrm{KCl}$ in the southern area of Merapi Mountain.
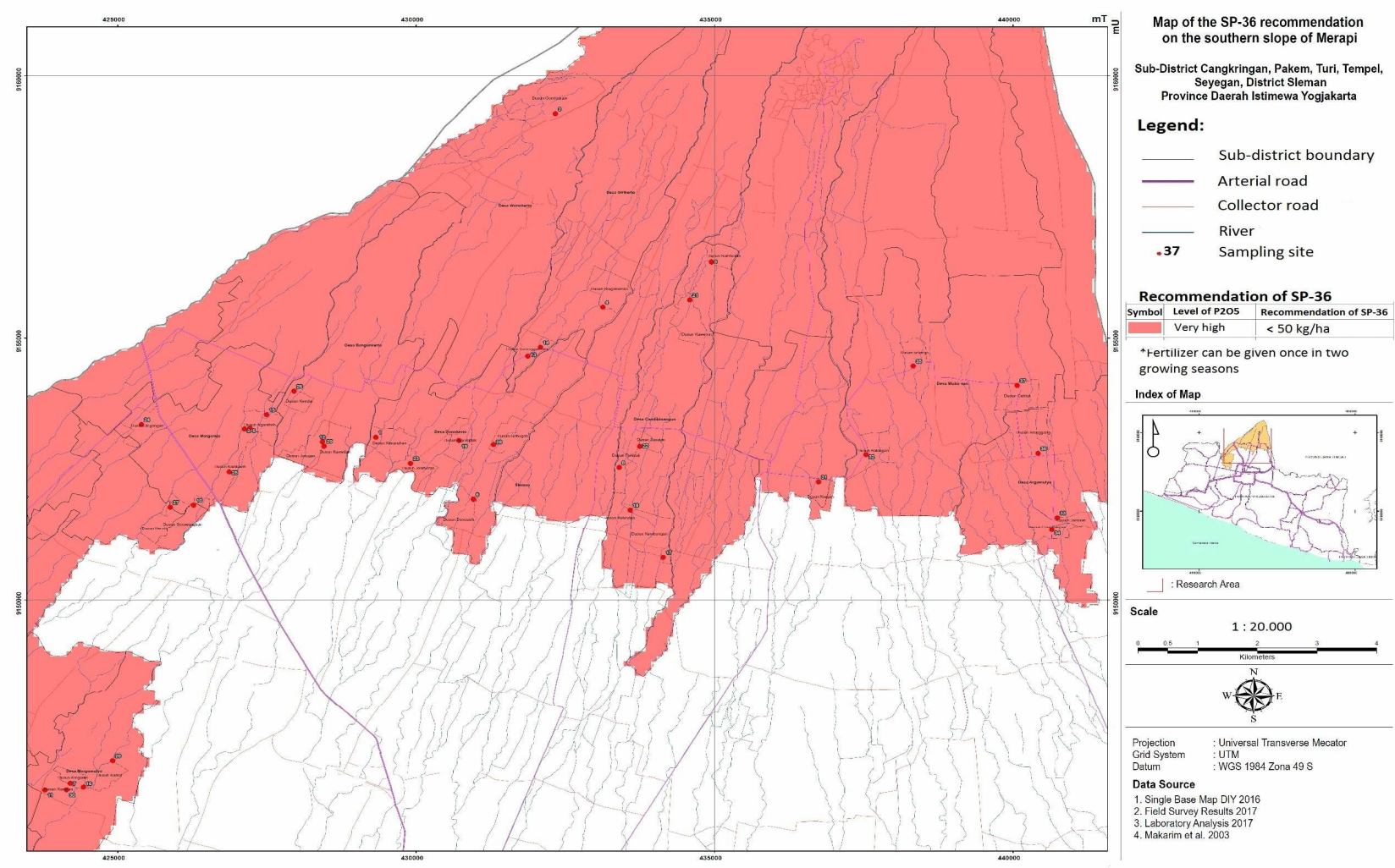

Fig. 7. Recommendation map of SP-36 in the southern area of Merapi Mountain.

Figure 6 also shows the recommendation of $\mathrm{KCl}$ fertilizer in combination with rice straw harvested from the rice field. The southern area of Merapi Mountain is dominated by low to medium $\mathrm{K}_{2} \mathrm{O}$ level. 
For the low-level area, it is recommended to apply 50 $\mathrm{kg} / \mathrm{ha}$ of $\mathrm{KCl}+$ harvested rice straw, whereas for the medium level area it is just required to give back the harvested straw to the soil and no $\mathrm{KCl}$ addition is needed. The use of the rice straw can economize the rice production process, especially the decrease in fertilizer expenses; it is hoped that an efficient and effective process of production will increase the farmer's income. Figure 7 shows that the southern area of Merapi Mountain is dominated by a very high soil phosphorus level ( $>60 \mathrm{mg} / 100 \mathrm{~g}$ of soil) so that the fertilizer recommendation is just to replenish the phosphorus after rice-harvesting. It is recommended to apply less than $50 \mathrm{~kg} / \mathrm{ha}$ of SP-36 fertilizer and only once a two rice-growing seasons. The farmer's habit to apply very intensively fertilization of the same dosage every season has caused an accumulation of phosphate in the soil and worsened the equilibrium of nutrients in the soil. The soil needs to be treated to utilize the high content of phosphate, so it could be transformed into a more available form and be absorbed by the plant.

\section{CONCLUSION}

An approach of digital soil mapping based on the major indigenous nutrients of the soil is extremely important in agriculture management. In broad outline, this approach covers a compilation of data, the elaboration of a soil fertility map, a distribution map of soil nutrient status and a map of fertilizer recommendations.

Results show that the base saturation status of soil along the southern area of Merapi Mountain was dominantly medium (41-60\%) and high (60-80\%). The $\mathrm{P}_{2} \mathrm{O}_{5}$ level in the area was very high $(>60 \mathrm{mg} / 100 \mathrm{~g}$ of soil). The $\mathrm{K}_{2} \mathrm{O}$ level in this area was dominantly very low (<10mg/100 g of soil) and low (10-20 10mg/100 g of soil). Due to the high content of phosphorus in the soil, it is recommended to apply less than $50 \mathrm{~kg} / \mathrm{ha}$ SP36 fertilizer. For potassium, it is recommended to apply alternative 2 in the low-level area with $50 \mathrm{~kg} / \mathrm{ha}$ of $\mathrm{KCl}$ + harvested rice straw, whereas for the medium level area just to recycle the harvested rice straws back to the soil. In addition to the investigated parameters, it is necessary to consider the chemical-physical properties of the soil.

The resulted recommendation map is highly applicable and easy to be used by farmers on providing a proper amount of fertilizer to the paddy-fields. In the case of fertilization of irrigated rice, it should be done site-specifically.

\section{ACKNOWLEDGEMENTS}

Dedicated to the Ministry of Research, Technology and Higher Education of the Republic of Indonesia for funding this study.

\section{REFERENCES}

Abdulrachman S., Susanti Z., Suhana (2000), Dinamika unsur NPK pada lahan sawah dalam jangka panjang (The dynamics of nitrogen, phosphorus and potassium elements on paddy-fields in the long term). Laporan akhir Proyek Pengkajian Teknologi Pertanian Partisipatif (PAATP). Sukamandi: Badan Penelitian dan Pengembangan Pertanian. [Report in Bahasa Indonesia].

Adiningsih S., Moersidi J. S., Sudjadi M., Fagi, A. M. (1989), Evaluasi keperluan fosfat pada lahan sawah intensifikasi di Jawa (Evaluation of phosphate need at intensified paddy-fields in Java). Prosiding Lokakarya Nasional Efisiensi Penggunaan Pupuk. Bogor: Pusat Penelitian Tanah. 63-89. [Proceedings in Bahasa Indonesia].

Bui E. (2006), Chapter 2 A Review of Digital Soil Mapping in Australia. Developments in Soil Science 31: 25-37. DOI: https://doi.org/10.1016/So166-2481(06) 31002-1.

Burt R. (2004), Soil Survey Laboratory Methods Manual: Soil Survey Investigations Report No. 42, Version 4.o. United States Department of Agriculture, Natural Resources Conservation Service.

Cressie N. A. C. (1990), The origins of kriging. Mathematical Geology, 22(3), 239-252. DOI: http://dx.doi.org/10.1007/BFoo889887

Dobermann A., Witt C., Abdulrachman S., Gines H. C., Nagarajan R., Son T. T., Tan P. S., Wang G. H., Chien N.V., Thoa V. T. K., Phung C. V., Stalin P., Muthukrishnan P., Ravi V., Babu M., Simbahan G. C., Adviento M. A. A., Bartolom V. (2003a), Estimating indigenous nutrient supplies for site-specific nutrient management in irrigated rice. Agronomy Journal, 95, 924-935. DOI:10.2134/agronj2003.9240

Dobermann A., Witt C., Abdulrachman S., Gines H. C., Nagarajan R., Son T. T., Tan P. S., Wang G. H., Chien N. V., Thoa V. T. K. (2003b), Soil fertility and indigenous nutrient supply in irrigated rice domains of Asia. Agronomy Journal, 95, 913-923. DOI:10.2134/agronj2003.0913.

FAO (1977), Soil and plant analysis as a basis of fertilizer recommendations. FAO Soil Bulletin No. 38/2. Rome: Food and Agriculture Organization of the United Nations.

FAO (1984), Guidelines: Land evaluation for rain-fed agriculture. FAO Soils Bulletin No. 52. Rome: Food and Agriculture Organization of the United Nations.

Haefele S. M., Johnson D. E., Diallo S., Wopereis M. C. S., Janin L. (200o), Improved soil fertility and weed management is profitable for irrigated rice farmers in the Sahelian West Africa. Field Crops Research, 66(2), 101-113. DOI: https://doi.org/10.1016/So378-4290(oo)00o66-6.

Accessed on 29.06.2018. 
Harahap A. J., Zaini Z., Sembiring H. (2002), Keterkaitan antara peta P dan K skala 1:250.000 dengan skala 1:50.000 sebagai dasar penentuan rekomendasi pemupukan pada lahan sawah (The relation between $\mathrm{P}$ and $\mathrm{K}$ maps of scale 1:250,000 and a scale of 1:50,000 as a basis for determining fertilizer recommendation in paddy-fields]. Prosiding Pengelolaan Hara P dan K pada Padi Sawah. Bogor: Pusat Penelitian Tanah dan Agroklimat, pp. 59-76. [Proceedings in Bahasa Indonesia]

van Reeuwijk L. P. (1993), Procedures for Soil Analysis. $4^{\text {th }}$ edition. Technical Paper, International Soil Reference and Information Centre. Wageningen, The Netherlands.

Küçüker M. A., Copty N., Oral M. G. V., Onay T. T., Yenigün O., Mater B. (2010), Kriging-based estimation of the change in soil carbon stock in the coastal Black Sea region, Turkey. Geophysical Research Abstracts, vol. 12. Vienna. EGU General Assembly 2010. p. 2036.

Lagacherie P. (2008), Digital Soil Mapping: A State of the Art. In: Hartemink A. E., McBratney A., Mendonça-Santos M. (eds) Digital Soil Mapping with Limited Data. Springer, Dordrecht. DOI: https://doi.org/10.1007/978-1-4020-8592-5_1.

Lagacherie P., McBratney A. B. (2007), Chapter 1 Spatial Soil Information Systems and Spatial Soil Inference Systems: Perspectives for Digital Soil Mapping. Developments in Soil Science, 31, 3-24. DOI: https://doi.org/10.1016/So166-2481(06)31001-X.

Accessed on 29.06.2018.

Makarim A. K., Widiarta I. N., Hendarsih S., Abdulrachman S. (2003), Panduan teknis pengelolaan hara dan pengendalian hama penyakit tanaman padi secara terpadu. [Technical guidance on integrated nutrient and pest management]. Bogor: Pusat Penelitian dan Pengembangan Tanaman Pangan. p. 37. [Book in Bahasa Indonesia].

McKenzie N. J., Ryan P. J. (1999), Spatial prediction of soil properties using environmental correlation. Geoderma, 89(1-2), 67-94. DOI: https://doi.org/10.1016/Soo16-7061(98)00137-2

Ming L., Klemens E., Zhang B., Holzhauer S. I., Li Z., Zhang T., Rauch S. (2011), Effect of intensive inorganic fertilizer application on microbial properties in a paddy soil of subtropical China. Agricultural Sciences in China, 10(11), 1758-1764. DOI: https://doi.org/10.1016/S1671-2927(11)60175-2

Mkhabela M., Warman P. R. (2005), The influence of municipal solid waste compost on yield, soil phosphorus availability and uptake by two vegetable crops, grown in a Pugwash sandy loam soil in Nova Scotia. Agriculture, Ecosystems \& Environment, 106(1), 57-67. DOI: https://doi.org/10.1016/j.agee.2004.07.014. Muralidharudu Y., Sammi Reddy K., Mandal B. N., Subba Rao A., Singh K. N., Sonekar S. (2011), GIS Based Soil Fertility Maps of Different States of
India. Indian Institute of Soil Science, Bhopal. pp. 1224.

Mushtaq A. W., Wani J. A., Bhat, M. A., Kirmani, N. A., Zahid, M. W., Shaista, N. B. (2013), Mapping of soil micronutrients in Kashmir agricultural landscape using ordinary kriging and indicator approach. Journal of the Indian Society Remote Sensing, 41(2), 319-329. DOI: https://doi.org/10.1007/s12524-012-0242-3.

Nahak T., Mishra K., Saren S., Pogula S. (2016), GPS and GIS based soil fertility maps of Ranital KVK farm and identification of soil related production constraints. International Journal of Agriculture Sciences, 8(51), 2242-2251. URL: https://bioinfo publication.org/files/articles/8_51_18_IJAS.pdf.

Accessed on 03.07. 2018.

Patton M. Q. (2001), Qualitative research and evaluation methods (2 ${ }^{\text {nd }}$ Edition). Thousand Oaks, California: Sage Publications.

Prasetyo B. H., Santosa D., Widowati L. R. (2012), Petunjuk Teknis Analisis Kimia Tanah, Tanaman, Air, dan Pupuk [Technical Guidelines for Chemical Analysis of Soil, Plants, Water, and Fertilizer]. Edisi ke-2. Bogor: Badan Penelitian dan Pengambangan Pertanian. Kementrian Pertanian Republik Indonesia. [Book in Bahasa Indonesia].

Pusat Penelitian Tanah (1983), Terms of reference, survai kapabilitas tanah [Terms of reference, a survey of soil capability]. Proyek Penelitian Pertanian Menunjang Transmigrasi (P3MT). Bogor: Pusat Penelitian Tanah, Badan Penelitian dan Pengembangan Pertanian. Kementrian Pertanian Republik Indonesia. [Book in Bahasa Indonesia].

Rao A. S., Srivastava S. (2000), Soil test based fertilizer use: a must for sustainable agriculture. In: Fertilizer News, 45, 25-38. URL: https://www.cab direct.org/cabdirect/abstract/20001912843. Accessed on 02.07.2018.

Rochayati S., Adiningsih S. (2002), Pembinaan dan pengembangan program uji tanah untuk hara $\mathrm{P}$ dan $\mathrm{K}$ pada lahan sawah [Creation and development of soil test program for $\mathrm{P}$ and $\mathrm{K}$ nutrients in paddy-fields]. Prosiding Pengelolaan Hara P dan K pada Padi Sawah. Bogor: Pusat Penelitian Tanah dan Agroklimat. pp. 937. [Book in Bahasa Indonesia].

Scull P., Franklin J., Chadwick O. A., McArthur D. (2003), Predictive soil mapping: A review. Progress in Physical Geography: Earth and Environment, 27(2), 171-197. DOI: https://doi.org/10.1191/o309133303 pp3 66ra.

Sharma P. K., Sood A., Setia R. K., Verma V. K., Mehra D., Tur N. S., Nayyar V. K. (2008), Mapping of macronutrients in soils of Amritsar District (Punjab) - A GIS approach. Journal of Indian Society of Soil Science, 56(1), 23-33. URL: https://www.researchgate.net/profile/Harpinder_Sin gh/publication/207037889_Mapping_of_macronutri 
ents_in_soils_of_Amritsar_district_Punjab_A_GIS_ approach/links/541d543aocf241a65a15e8a7/Mapping -of-macronutrients-in-soils-of-Amritsar-district-

Punjab-A-GIS-approach.pdf. Accessed on 30.06.2018.

Shukla G., Mishra G. C., Singh S. K. (2015), Kriging approach for estimating deficient micronutrients in the soil: A case study. International Journal of Agriculture, Environment and Biotechnology, 8(2), 309-314. DOI: 10.5958/2230732X.2015.00038.8
Vadivelu S. (2007), Soils of coastal ecosystem in the southern states and their problems and potentials for land use planning. Proceedings of National Symposium on Soil Science Research, Indian Society of Soil Science, Kolkata, December, 7-9, pp. 31-35. URL: https://www.researchgate.net/publication/307950011_ GIS_Applications_in_Agronomy. Accessed on 28.06.2018. 